\title{
Targeted CDX2 expression inhibits aggressive phenotypes of colon cancer cells in vitro and in vivo
}

\author{
JIANBAO ZHENG $^{1 *}, \mathrm{SAI} \mathrm{HE}^{2 *}, \mathrm{JIE} \mathrm{QI}^{3}$, XIAOLONG WANG ${ }^{4}, \mathrm{JUNHUI} \mathrm{YU}^{1}$,

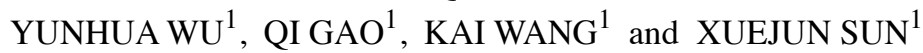 \\ ${ }^{1}$ Department of General Surgery, The First Affiliated Hospital of Xi'an Jiaotong University; ${ }^{2}$ Department of Breast Surgery, \\ Shaanxi Provincial Tumor Hospital, Xi'an, Shaanxi 710061; ${ }^{3}$ Second Department of Cardiovascular Medicine, \\ Shaanxi Provincial People's Hospital, Xi'an, Shaanxi 710068; ${ }^{4}$ Department of Tumor Surgery, The Second \\ Affiliated Hospital of Medical College, Xi'an Jiaotong University, Xi'an, Shaanxi 710004, P.R. China
}

Received January 30, 2017; Accepted May 31, 2017

DOI: $10.3892 /$ ijo.2017.4040

\begin{abstract}
Loss of caudal type homeobox 2 (CDX2) is associated with the development of human colorectal cancer, while human telomerase reverse transcriptase (hTERT) frequently occurs in variety of human cancers. We investigated the effects of restoration of CDX2 expression using a hypoxia-inducible hTERT promoter-driven vector (pLVX-5HRE-hTERTp-CDX23FLAG) on colon cancer cell viability, cell cycle distribution, apoptosis, colony formation, invasion ability and xenograft tumor growth in nude mice. CDX2 overexpression significantly inhibited viability, colony formation, and the invasion and migration ability of LoVo cells, and induced cell cycle arrest and apoptosis in vitro, especially under hypoxic culture conditions. Overexpression of CDX2 under normoxic conditions significantly suppressed the expression of TGF- $\beta$, cyclin D1, uPA, MMP-9, MMP-2, and Bcl-2, and stimulated the expression of collagen IV, laminin-1, and Bax. Overexpression of CDX2 reduced colon cancer xenograft tumor formation in nude mice which was associated with downregulation of Ki-67. In conclusion, overexpression of CDX2 using a hypoxia-inducible hTERT promoter-driven vector suppressed malignant progression of colon cancer cells in vitro and in vivo. These results suggest that pLVX-5HRE-hTERTp-CDX2-3FLAG gene therapy may be a promising novel approach to treat colon cancer.
\end{abstract}

\section{Introduction}

Colorectal cancer is the third most common cancer in the world, with nearly 1.4 million new cases diagnosed in 2016 (1).

Correspondence to: Professor Xuejun Sun, Department of General Surgery, The First Affiliated Hospital of Xi'an Jiaotong University, 277 West Yanta Road, Xi'an, Shaanxi 710061, P.R. China

E-mail: sunxysky@163.com

*Contributed equally

Key words: hypoxia response element, human telomerase catalytic subunit, CDX2, malignant progression, colon cancer
Currently, methods of treatment for colorectal cancer include surgery, radiotherapy, chemotherapy, and immunotherapy. However, the curative effect of these methods, particularly for advanced colorectal cancer, is limited (2-4). Tumor-targeted gene therapy is a new and promising method for the effective treatment of colorectal cancer. Gene therapy that uses vectors to bring nucleic acids into cells to alter gene expression can prevent or reverse malignant progression of the tumor. The clinical trials on gene therapy are increasing worldwide. Although tumor-selective delivery systems have made significant progress in the past 20 years, development of therapeutic vectors based on promoters that are specifically expressed in cancer cells is still a challenge. Therefore, many strategies use specific gene enhancers, promoters, and 5'-untranslated regions that respond to tumor-targeted transcription factors, in order to overexpress tumor suppressor genes or to reduce cancer gene expression, have appeared.

In this study, we focused on the intestinal transcription factor caudal type homeobox 2 (CDX2). CDX2 participates in the development, proliferation, and differentiation of intestinal epithelial cells (5-7). Furthermore, CDX2 reduces the mobility and dissemination of colon cancer cells both in vitro and in vivo (8). CDX2 has tumor-inhibition properties in colorectal cancer (9-11), reduced CDX2 expression is connected with poor survival in patients with colorectal cancer (12). In our previous studies, forced expression of CDX2 by a cytomegalovirus promoter inhibited invasion of LoVo colon cancer cells (13). However, targeted expression of CDX2 to cancer cells is required.

In most cancer cells, but not normal cells, the human telomerase reverse transcriptase (hTERT) promoter is activated $(14,15)$. Therefore, the hTERT promoter has been used in many tumor-targeted gene therapy studies to target cancer cells, including A549 human lung adenocarcinoma cells and human gastric cancer MKN45 cells $(16,17)$.

Hypoxia is a major feature of solid tumors and induces hypoxia-inducible factor- $1 \alpha$ (HIF-1 $\alpha$ ) which binds to the hypoxia-response elements (HREs) of various target genes and activates their transcription to regulate glucose transport and angiogenesis, and potentially enhance the survival of tumor cells (18-22). Our previous studies have shown that 
hypoxia modulates the downregulation of CDX2 in colorectal cancer (23). In contrast, in this study we engineered a system in which hypoxia promotes CDX2 expression. To restore CDX2 expression in colon cancer cells, we constructed an expression vector carrying CDX2 under the control of the hypoxia-inducible hTERT promoter (pLVX-5HRE-hTERTpCDX2-3FLAG). Targeted genes simultaneously can be dramatically upregulated by 5 copies of a hypoxia response element (HRE) under hypoxic conditions $(24,25)$.

We evaluated the effects of restored CDX2 expression on LoVo colon cancer cell viability, cell cycle distribution, apoptosis, and colony formation and invasion ability in vitro and on xenograft tumor growth in vivo. This study further explored potential strategies of targeted gene therapy for colon cancer.

\section{Materials and methods}

Cell lines and cell cultures. All cell lines were purchased from the Shanghai Institute of Cell Biology, Chinese Academy of Sciences (Shanghai, China). The LoVo human colon cancer cells were cultured in DMEM (Gibco BRL, Carlsbad, CA, USA) supplemented with 10\% FBS (Hyclone, Logan, UT, USA) in a humidified atmosphere with $5 \% \mathrm{CO}_{2}$ at $37^{\circ} \mathrm{C}$. For hypoxic cell culture, cells were incubated with medium containing a hypoxia-mimicking agent, $\mathrm{CoCl}_{2}$.

Lentivirus infection of LoVo cells. The recombinant plasmid pLVX-5HRE-hTERTp-CDX2-3FLAG (designated as 5HhC) and the control plasmids pLVX-5HRE-hTERTp-EGFP3FLAG (i.e., 5Hh) and pLVX-hTERTp-CDX2-3FLAG (i.e., hC) have been previously described (26). These vectors and corresponding viruses $\left(1 \times 10^{8} \mathrm{pfu}\right)$ were custom constructed and prepared by GeneChem Co. Lentivirus infection was performed in the presence of polybrene (GeneChem) in accordance with the manufacturer's protocol. LoVo cells at $5 \times 10^{5} /$ well were cultured in 6 -well plates overnight, infected with $5 \mathrm{HhC}$ lentivirus or control $5 \mathrm{Hh}$ and hC lentiviruses, and exposed to puromycin $(800 \mu \mathrm{g} / \mathrm{ml})$ for 2 weeks. The $5 \mathrm{HhC} / \mathrm{LoVo}, 5 \mathrm{Hh} / \mathrm{LoVo}$, and $\mathrm{hC} / \mathrm{LoV}$ o cells were cloned routinely. Drug-resistant clones were identified and used in the following experiments.

Western blot analysis. The hC/LoVo, 5Hh/LoVo, 5HhC/LoVo, and untransfected LoVo cells were cultured under normoxic or hypoxic conditions $\left(200 \mu \mathrm{mol} / 1 \mathrm{CoCl}_{2}\right)$ for $24 \mathrm{~h}$. The relative ratios of CDX2, collagen IV, laminin-1, TGF- $\beta$, cyclin D1, uPA, MMP-2, MMP-9, bcl-2, and bax protein to control $\beta$-actin were determined by western blot analysis. Briefly, the hC, $5 \mathrm{Hh}$ or $5 \mathrm{HhC}$ lentivirus-infected LoVo cells $\left(1 \times 10^{6}\right.$ cells) were lysed with $150 \mu \mathrm{l}$ of lysis buffer (50 mM Tris, $150 \mathrm{mM}$ $\mathrm{NaCl}, 5 \mathrm{mM}$ ethylenediaminetetraacetic acid (EDTA), $5 \mathrm{mM}$ EGTA and 1\% SDS, pH 7.5) and gently sonicated. After quantification with Bradford reagent (Thermo Fisher Scientific, Waltham, MA, USA), the protein lysates ( $80 \mu \mathrm{g} /$ lane) of each sample were subjected to SDS-PAGE (Shaanxi Pioneer Biotech) on $10 \%$ acrylamide gels and transferred to polyvinylidene fluoride membranes (Millipore, Billerica, MA, USA). After blocking with $5 \%$ fat-free dry milk, the membranes were incubated with 1:1000 diluted monoclonal rabbit antiCDX2 (Epitomics, Burlingame, CA, USA) or 1:3000 diluted polyclonal rabbit anti- $\beta$-actin (Bioworld Technology, St. Louis Park, MN, USA) overnight at $4^{\circ} \mathrm{C}$, and then horseradish peroxidase-conjugated goat anti-rabbit IgG secondary antibody (Zhongshan Goldbridge Biotechnology, Beijing, China). This was visualized with enhanced chemiluminescence (Amresco, Solon, OH, USA).

Reverse transcriptase polymerase chain reaction (RT-PCR) and quantitative RT-PCR analysis. The hC/LoVo, 5Hh/LoVo, $5 \mathrm{HhC} / \mathrm{LoV}$ and LoVo cells were cultured under normoxic or hypoxic conditions $\left(200 \mu \mathrm{mol} / 1 \mathrm{CoCl}_{2}\right)$, and the transcription of recombinant CDX 2 mRNA was determined by RT-PCR using the primers listed in Table I. In brief, total RNA was extracted from the infected cells using TRIzol (Gibco Life Technologies, Grand Island, NY, USA), in accordance with the manufacturer's guidelines. The resulting RNAs were treated with RNase-free DNase (Promega, Madison, WI, USA) and reverse transcribed into cDNA using a RT-PCR kit (Invitrogen, Carlsbad, USA), in accordance with the manufacturer's instructions. PCR amplification with the specific primers (Table I) was performed in duplicate at $98^{\circ} \mathrm{C}$ for $2 \mathrm{~min} ; 35$ cycles of $98^{\circ} \mathrm{C}$ for $20 \mathrm{sec}, 59^{\circ} \mathrm{C}$ for $30 \mathrm{sec}$, and at $72^{\circ} \mathrm{C}$ for $1 \mathrm{~min}$; and then an extension at $72^{\circ} \mathrm{C}$ for $10 \mathrm{~min}$. The PCR products were resolved via agarose gel electrophoresis. RT-PCR was performed in triplicate for each cell sample using a ChemiDoc System (ChemiDoc MP System 170-8280; Bio-Rad Laboratories). The cDNA was subjected to quantitative RT-PCR analysis of CDX2 mRNA using SYBR Premix Ex Taq II (Takara) and specific primers (Table I) in an iQ5 multicolor Realtime PCR Detection System (Bio-Rad, Hercules, CA, USA). Each reaction was performed in triplicate and the mean CDX2 mRNA level in each group was calculated by the $2^{-\Delta \Delta \mathrm{Ct}}$ method, where $\mathrm{Ct}$ is the cycle threshold.

MTT assay. The growth of LoVo cells of all experimental groups was measured by methyl thiazol tetrazolium (MTT) assay. The cells (hC/LoVo, 5Hh/LoVo, 5HhC/LoVo, and LoVo; 5x10³/well in triplicate) were cultured under normoxic or hypoxic conditions $\left(200 \mu \mathrm{mol} / 1 \mathrm{CoCl}_{2}\right)$ for $1,3,5$ or 7 days. Subsequently, the plates were washed extensively with serum-free DMEM to remove $\mathrm{CoCl}_{2}$ and dead cells, and were exposed to $20 \mu \mathrm{l}(5 \mathrm{~g} / \mathrm{l})$ of MTT (Amersco) for $4 \mathrm{~h}$. The resulting formazan crystals were dissolved in $200 \mu \mathrm{l}$ of DMSO (Sigma-Aldrich), and the absorbance was measured at $490 \mathrm{~nm}$ in a microplate reader (Victor3, Perkin-Elmer, Waltham, MA, USA).

Colony formation assay. Two hundred cells (hC/LoVo, $5 \mathrm{Hh} / \mathrm{LoVo}, 5 \mathrm{HhC} / \mathrm{LoVo}$, or LoVo), plated in 60-mm cell culture dishes, were cultured for 3 weeks. The hypoxic group was also treated with $\mathrm{CoCl}_{2}(200 \mu \mathrm{mol} / \mathrm{l})$. Colony-forming clones were fixed with methanol at room temperature for $15 \mathrm{~min}$ and then stained with Giemsa solution, and clones containing 50 or more cells were considered to be true clones. Colonies were counted under an inverted microscope (Leica Microsystems $\mathrm{GmbH}$, Heidelberg, Germany).

Flow cytometric apoptosis and cell cycle distribution assays. The hC/LoVo, 5Hh/LoVo, 5HhC/LoVo and LoVo cells were seeded into 60-mm culture dishes and the hypoxia group was treated with $\mathrm{CoCl}_{2}(200 \mu \mathrm{mol} / \mathrm{l})$ for $24 \mathrm{~h}$. For analysis of apoptosis, an FITC Annexin V Apoptosis detection kit I (Becton 
Table I. Sequences of PCR primers.

\begin{tabular}{|c|c|c|c|c|}
\hline Gene & & Primer & Base sequence $5^{\prime}-3^{\prime}$ & PCR product (bp) \\
\hline CDX2 & RT-PCR & $\begin{array}{l}\text { Forward } \\
\text { Reverse }\end{array}$ & $\begin{array}{l}\text { CGGAATTCATGTACGTGAGCTACC } \\
\text { TCCTGGACAAGGAC } \\
\text { CGGGATCCGTCTGGGTGACGGTG } \\
\text { GGGTTTAGCACCCCCCCAGTTG }\end{array}$ & 943 \\
\hline CDX2 & Quantitative RT-PCR & $\begin{array}{l}\text { Forward } \\
\text { Reverse }\end{array}$ & $\begin{array}{l}\text { TTCACTACAGTCGCTACATCACC } \\
\text { ACTGCGGTTCTGAAACCAGATT }\end{array}$ & 100 \\
\hline$\beta$-actin & $\begin{array}{l}\text { RT-PCR and } \\
\text { quantitative RT-PCR }\end{array}$ & $\begin{array}{l}\text { Forward } \\
\text { Reverse }\end{array}$ & $\begin{array}{l}\text { AATCTGGCACCACACCTTCTA } \\
\text { ATAGCACAGCCTGGATAGCA }\end{array}$ & 170 \\
\hline
\end{tabular}

Dickinson, Franklin Lakes, NJ, USA) was used, in accordance with the manufacturer's instructions. For cell cycle analysis, cells were fixed overnight in $75 \%$ ethanol at $-20^{\circ} \mathrm{C}$, incubated with RNase A at $37^{\circ} \mathrm{C}$ for $30 \mathrm{~min}$, and then incubated with propidium iodide at room temperature for $30 \mathrm{~min}$. Cells were examined by flow cytometry and the data were analyzed using CellQuest version 3.3 software (Becton Dickinson).

Wound-healing assay. The cells (hC/LoVo, $5 \mathrm{Hh} / \mathrm{LoVo}, 5 \mathrm{HhC} /$ LoVo and LoVo; $2 \times 10^{4}$ ) were cultured in a 6-well plate. After $12 \mathrm{~h}$ of culture, pipette tips $(200 \mu \mathrm{l})$ were used to scratch 3 parallel vertical lines in each well. The wells were washed with PBS, and then the cells were cultured in serum-free DMEM. Scratch lines were observed under a microscope and scratch distances were measured, with images captured at $24 \mathrm{~h}$ after scratching.

Migration and invasion assay. For the migration assay, all groups of cells (hC/LoVo, 5Hh/LoVo, 5HhC/LoVo, and LoVo) were digested with trypsin-EDTA (Sigma, St. Louis, MO, USA), and $5 \times 10^{3}$ cells were suspended in serum-free medium supplemented with $0.5 \%$ bovine serum albumin (BSA; Sigma). For the hypoxia group, $\mathrm{CoCl}_{2}\left(200 \mu \mathrm{mol} / 1 \mathrm{CoCl}_{2}\right)$ was also added to all cells before digestion. Cell suspensions were seeded into the inserts of Transwells (Corning Inc., New York, $\mathrm{NY}$, USA) and incubated at $37^{\circ} \mathrm{C}$ for $48 \mathrm{~h}$. All Transwell inserts were then washed with fresh PBS and non-migratory cells on the upper surface of the Transwell inserts were removed. The migratory cells on the underside of the membrane were fixed with $95 \%$ alcohol and stained with crystal violet (Beyotime, Jiangsu, China). For the invasion assay, the upper chamber was pre-coated with $50 \mathrm{mg} / \mathrm{l}$ Matrigel (Sigma) prior to the addition of $1 \times 10^{4}$ cells in serum-free medium supplemented with BSA. The number of migratory or invading cells per membrane was counted under an inverted microscope. Three randomly selected fields of fixed cells were taken and counted.

Nude mouse xenograft assay. All animal procedures were approved by the Institutional Animal Care and Use Committee at the First Affiliated Hospital of Xi'an Jiaotong University. Four-week-old female BALB/c athymic (nude) mice with body weights of approximately $20 \mathrm{~g}$ were purchased from Shanghai SLAC Laboratory Animal Co. Ltd. (Shanghai, China) and housed in the Laboratory Animal Centre of Xi'an
Jiaotong University. After one week of acclimatization, all nude mice were randomly divided into four groups (hC/LoVo, 5Hh/LoVo, 5HhC/LoVo, and LoVo). The mice were subcutaneously inoculated at the right flanks with cells $\left(1 \times 10^{7} / \mathrm{ml}\right)$ of the four groups in the logarithmic growth period. At 18 days post-injection, tumor sizes were monitored every 3 days using calipers, and tumor volumes were calculated according to the standard formula: width ${ }^{2} \mathrm{x}$ length $/^{2}$ and expressed as $\mathrm{mm}^{3}(27)$. At the end of 18 days, the mice were sacrificed by cervical dislocation and the tumor tissues of each group were fixed with $10 \%$ formaldehyde (Boster Biological Engineering) solution for subsequent immunohistochemical analysis.

Immunohistochemistry. Tumor tissues were embedded in paraffin (Xi'an Chemical Reagents Instruments, Xi'an, China) and the tissue sections $(4-\mu \mathrm{m})$ were immunostained for CDX2 (1:400) or Ki-67 (1:400). In accordance with the manufacturer's instructions, an ABC Elite kit (Boster, Biological Technology) was used to visualize antibody binding, and the slides were subsequently counterstained with hematoxylin (Boster Biological Engineering). Negative controls were included by replacement of the primary antibody with PBS. Images were captured using a microscope (Leica Microsystems $\mathrm{GmbH}$ ). The intensity of the staining was scored as 1 (negative), 2 (weakly positive), 3 (moderately positive) or 4 (strongly positive). The extent of the staining was categorized as 1 (stained cells: $1-25 \%), 2(26-50 \%), 3(51-75 \%)$ or 4 (76-100\%). The final staining score was the product of the intensity and the extent scores. Images of five random fields were taken from each specimen for quantitative analysis (28).

Statistical analysis. The data are representative of three independent experiments and are presented as the mean \pm standard deviation (SD). A two-sample t-test was performed to analyze two independent samples, whereas analysis of variance was conducted for comparison among multiple groups. SPSS 13.0 software (SPSS, Chicago, IL, USA) was used to calculate the $\mathrm{P}$-value and a $\mathrm{P}<0.05$ was considered to indicate a statistically significant difference.

\section{Results}

Expression of CDX2 in hC/LoVo, LoVo, 5Hh/LoVo, 5HhC/LoVo under normoxic or hypoxic conditions. To investigate the role 
$\mathbf{A}$

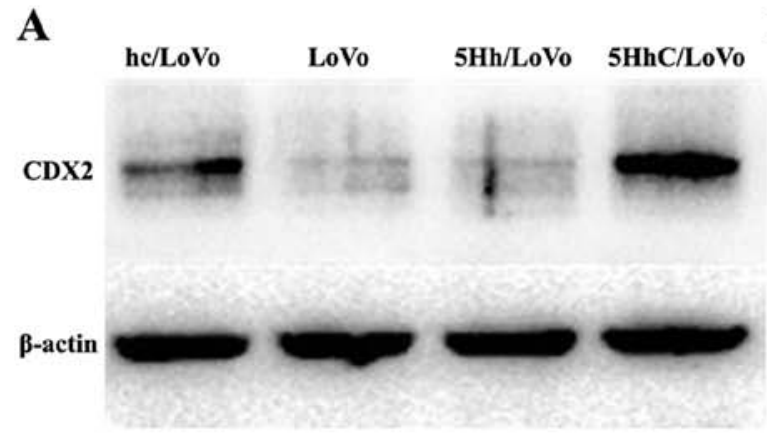

B

C

Normoxia

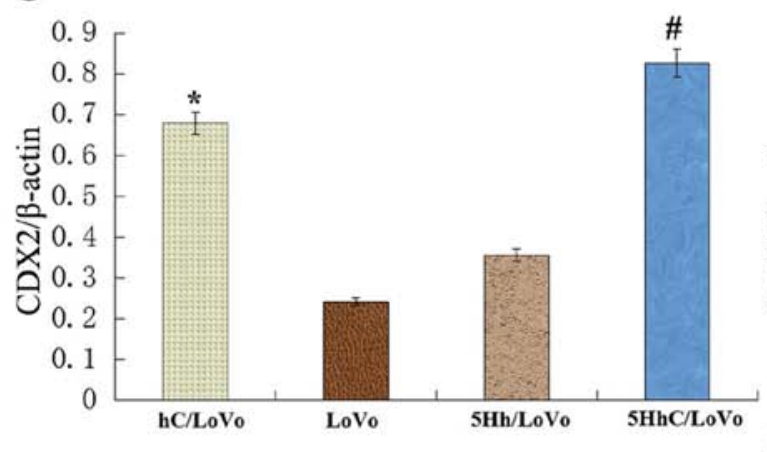

D

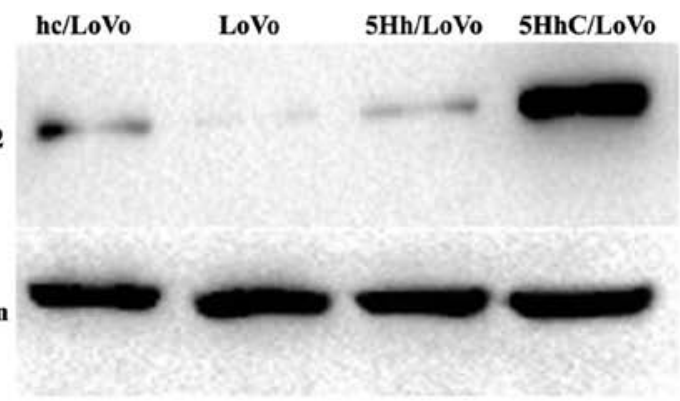

Hypoxia

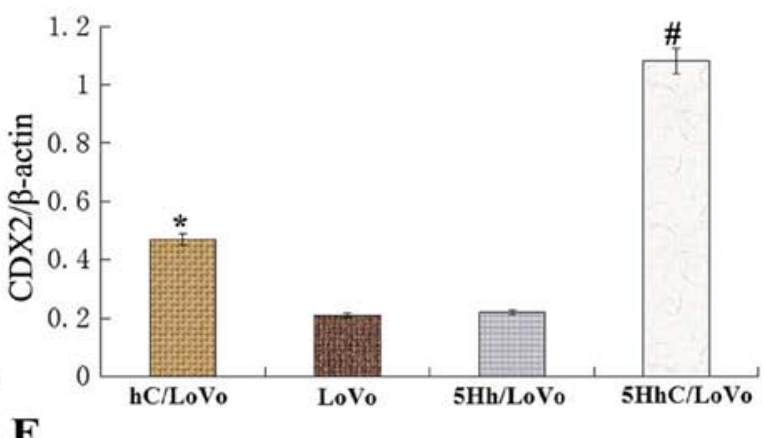

$\mathbf{E}$
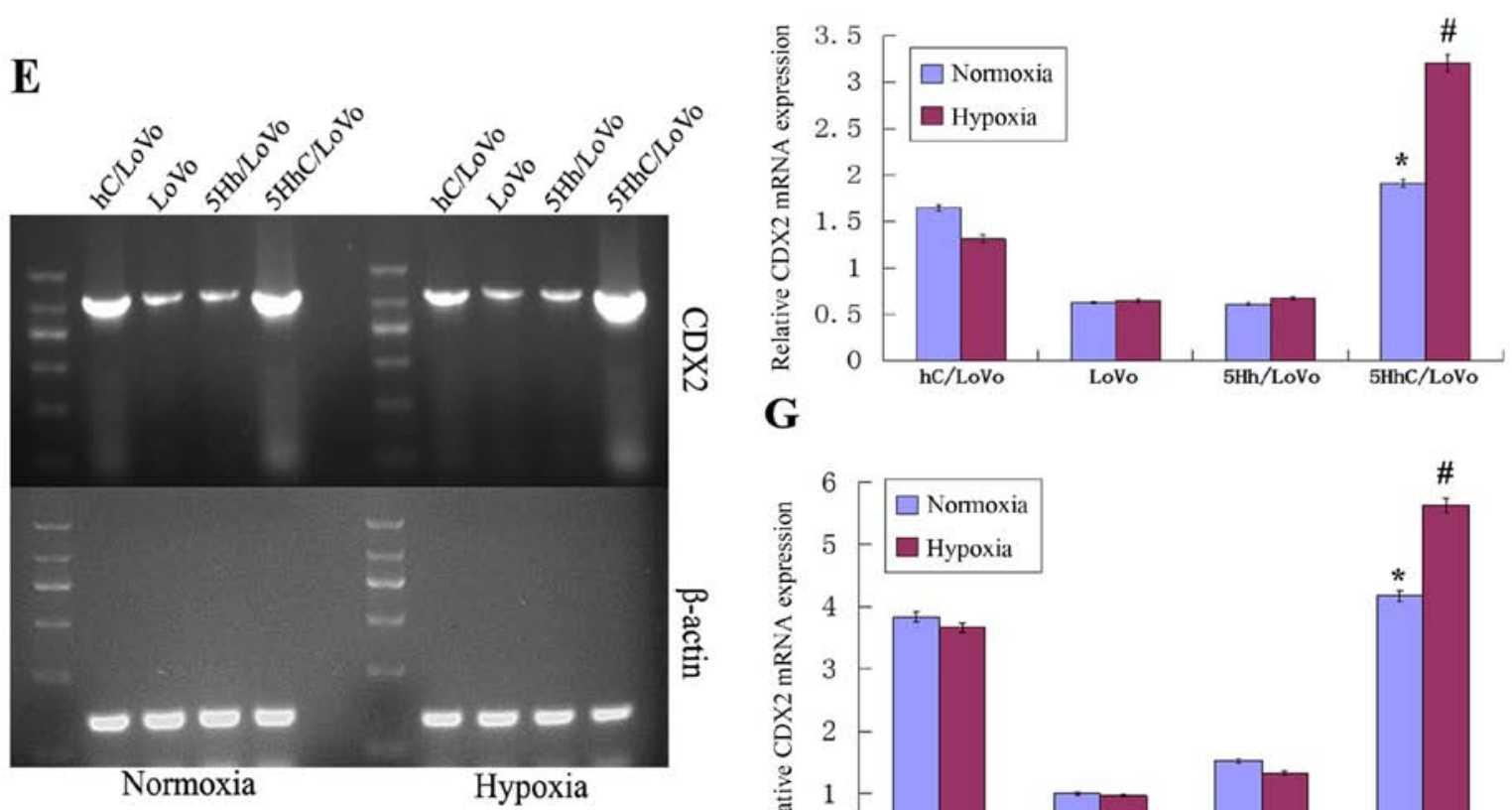

G

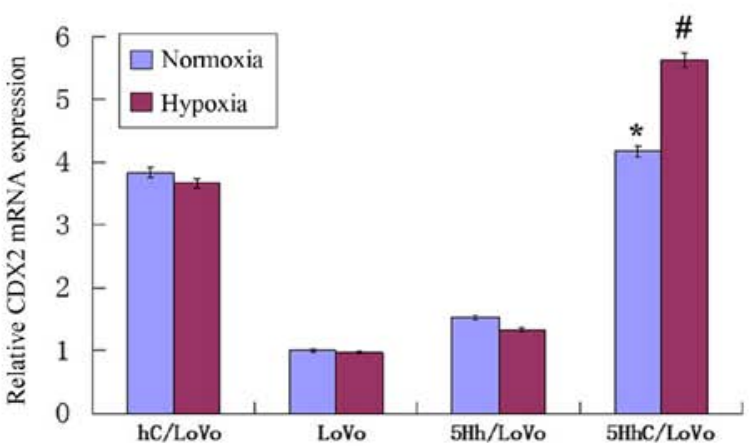

Figure 1. Expression levels of CDX2 in LoVo cells in all experimental groups under normoxic and hypoxic conditions. (A and C) Western blot analysis of CDX2 expression under normoxic conditions. (" $\mathrm{P}<0.05$ compared to LoVo, $5 \mathrm{Hh} / \mathrm{LoVo}$; ${ }^{\prime} \mathrm{P}<0.01$ compared to LoVo, $5 \mathrm{Hh} / \mathrm{LoVo}$ ); (B and D) Western blot analysis of CDX2 expression under hypoxic conditions $\left(200 \mu \mathrm{mol} / 1 \mathrm{CoCl}_{2}\right)$ for $24 \mathrm{~h} .\left({ }^{*} \mathrm{P}<0.05\right.$ compared to LoVo, $5 \mathrm{Hh} / \mathrm{LoVo}$; ${ }^{*} \mathrm{P}<0.01 \mathrm{compared}$ to LoVo, $\left.5 \mathrm{Hh} / \mathrm{LoVo}\right)$. (E and F) RT-PCR analysis of CDX2 mRNA expression under normoxic or hypoxic conditions $\left(200 \mu \mathrm{mol} / 1 \mathrm{CoCl}_{2}\right)$ for $24 \mathrm{~h}$. ("P $<0.05 \mathrm{compared}$ to LoVo, 5Hh/LoVo under normoxia; ${ }^{~} \mathrm{P}<0.01$ compared to LoVo, $5 \mathrm{Hh} / \mathrm{LoV}$ o and $\mathrm{hC} / \mathrm{LoVo}$ under hypoxia); (G) Real-time RT-PCR analysis of CDX2 mRNA expression. ( $\mathrm{P}<0.05$ compared to LoVo, $5 \mathrm{Hh} / \mathrm{LoVo}$ under normoxia; ${ }^{*} \mathrm{P}<0.01$ compared to LoVo, $5 \mathrm{Hh} / \mathrm{LoVo}$ and $\mathrm{hC} / \mathrm{LoV}$ o under hypoxia). The data shown are representative images of each group of cells from 3 separate experiments. The results are shown as means \pm SD.

of CDX2 expression in LoVo colon cancer cells, we stably transfected LoVo cells with $5 \mathrm{HhC}$ or its control plasmids hC or $5 \mathrm{Hh}$ expression vector. We confirmed the expression of CDX2 in transfected LoVo cells, especially under hypoxic conditions, by western blot (Fig. 1A-D), RT-PCR (Fig. 1E and F) and real-time PCR (Fig. 1G). Compared to the control LoVo cells, mock-transfected cells, or cells transfected with the $5 \mathrm{Hh}$ vector, the expression of CDX2 was higher in $\mathrm{hC} / \mathrm{LoVo}$ and $5 \mathrm{HhC} / \mathrm{LoV}$. The highest expression of CDX2 was observed in $5 \mathrm{HhC} / \mathrm{LoVo}$ cells under hypoxic conditions $(\mathrm{P}<0.01)$. 
A

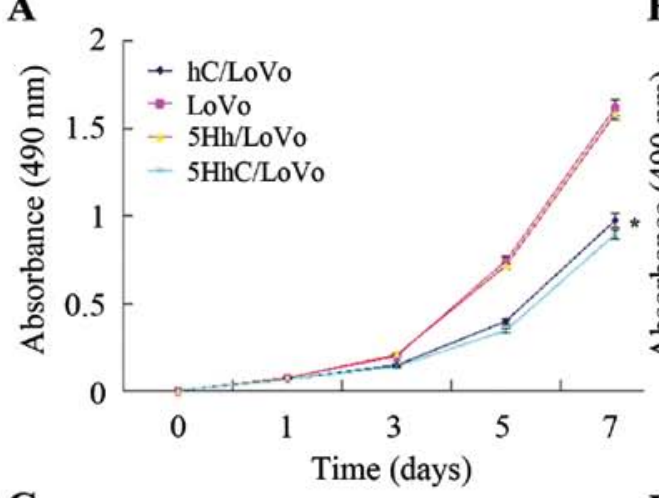

C

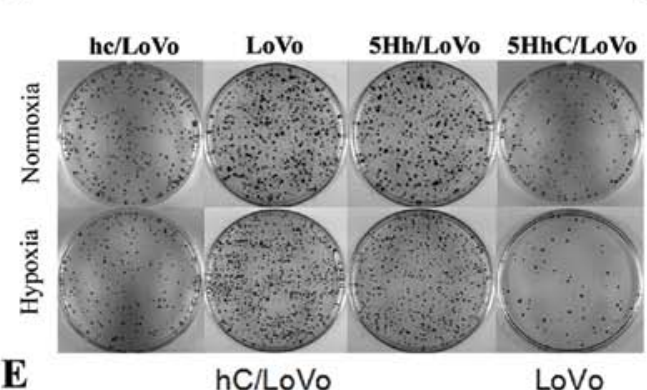

Lovo
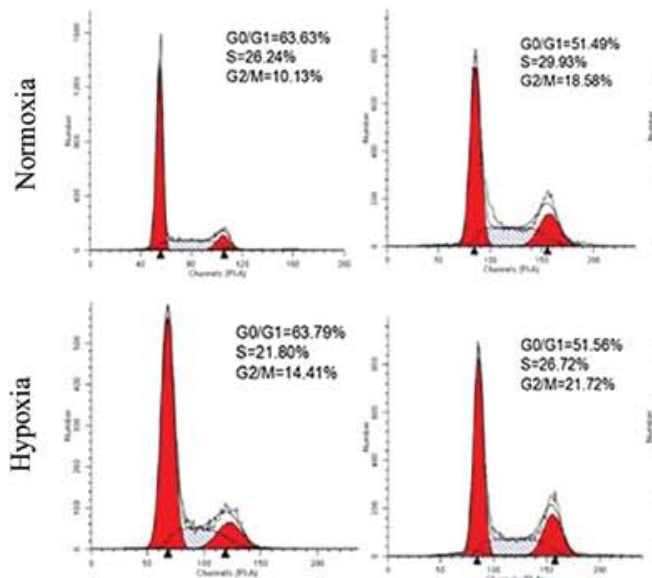

D
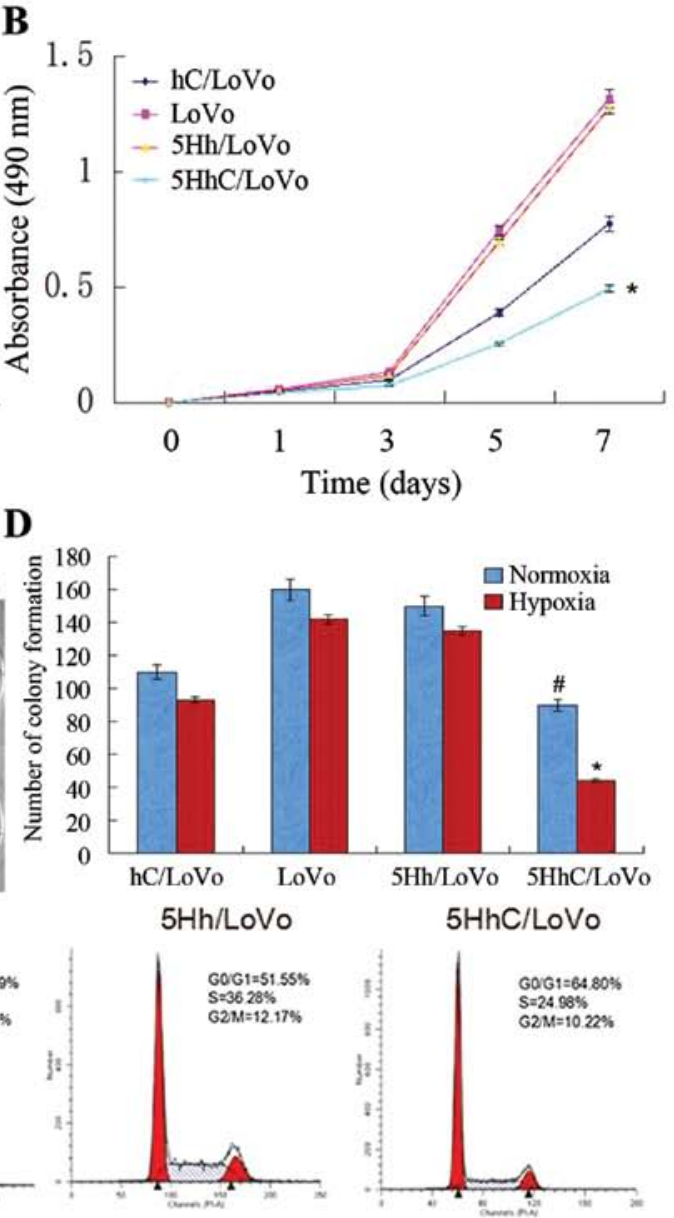

$\mathbf{F}$
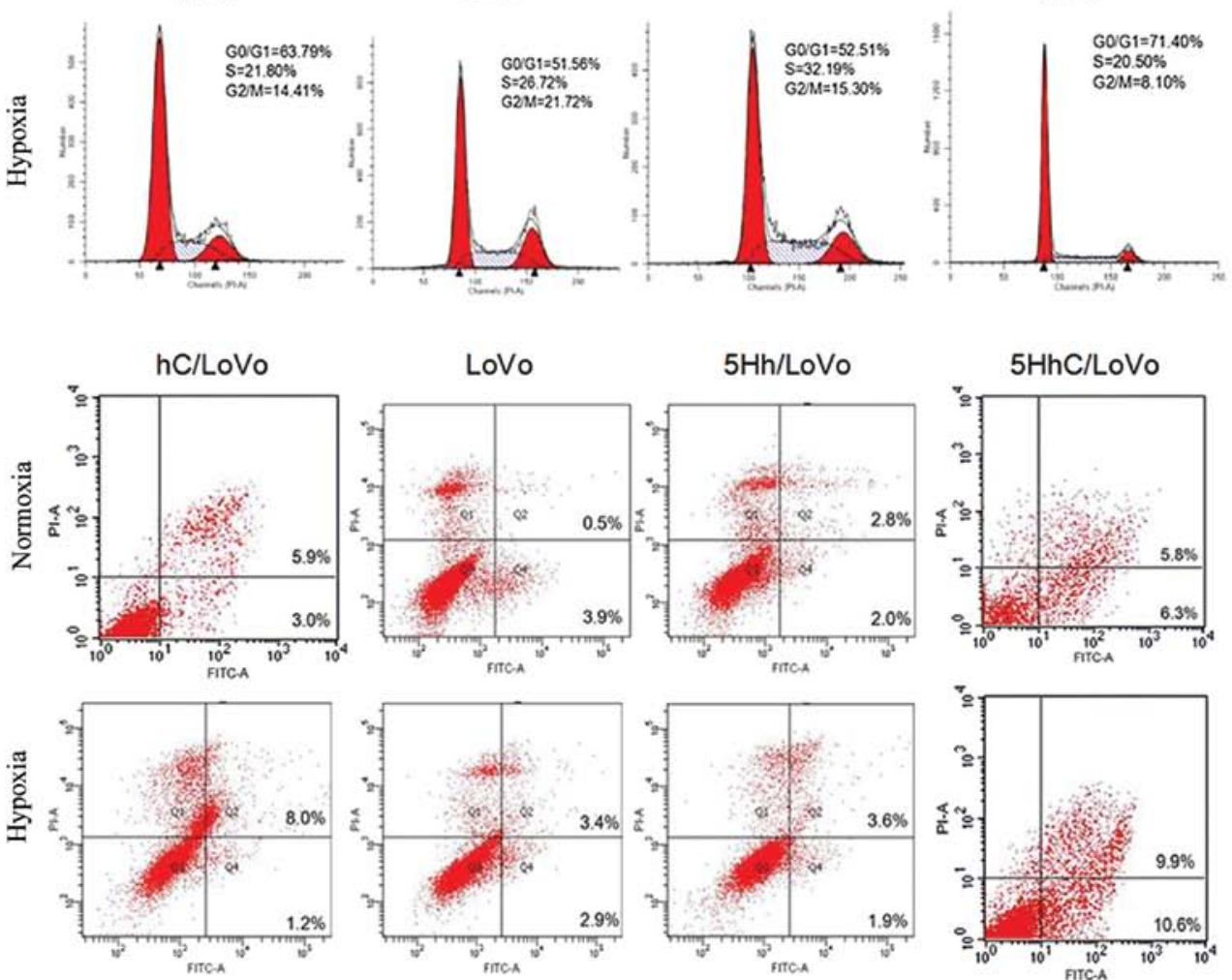

Figure 2. 5HhC inhibits proliferation and clonogenicity by restraining the $\mathrm{G} 1$ to $\mathrm{S}$ transition and induces apoptosis in colorectal cancer cells, especially under hypoxia. (A) Cell proliferation curve of $5 \mathrm{HhC}$ and control transfected cells by MTT assay under normoxic conditions. ( $\mathrm{P}<0.05$ compared to LoVo, $5 \mathrm{Hh} / \mathrm{LoVo}$ under normoxia); (B) Cell proliferation curve of $5 \mathrm{HhC}$ and control transfected cells by $\mathrm{MTT}$ assay under hypoxic conditions $\left(200 \mu\right.$ mol $/ 1 \mathrm{CoCl}{ }_{2}$; ${ }^{*} \mathrm{P}<0.05$ compared to hc/LoVo, LoVo, $5 \mathrm{Hh} / \mathrm{LoV}$ under hypoxia). (C) Clone formation by $5 \mathrm{HhC}$ and control cells; (D) Quantification of clone numbers showing high/low values $\left({ }^{\#} \mathrm{P}<0.05\right.$ compared to LoVo, 5Hh/LoVo under normoxia; ${ }^{*} \mathrm{P}<0.05$ compared to hc/LoVo, LoVo, $5 \mathrm{Hh} / \mathrm{LoVo}$ under hypoxia). (E) Cell cycle analysis of $5 \mathrm{HhC}$ and control cells. Percentages of cells in each phase of the cell cycle are indicated. (F) 5HhC induced apoptosis in human colorectal cancer cells, especially under hypoxia. The data shown are representative images of each group of cells from 3 separate experiments. The results are shown as means \pm SD. 
A
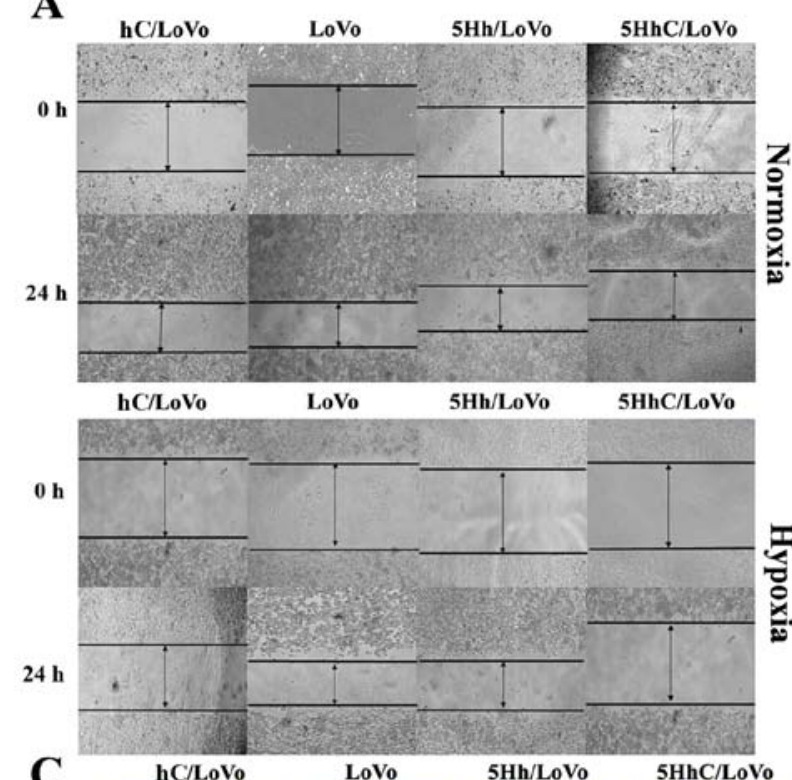

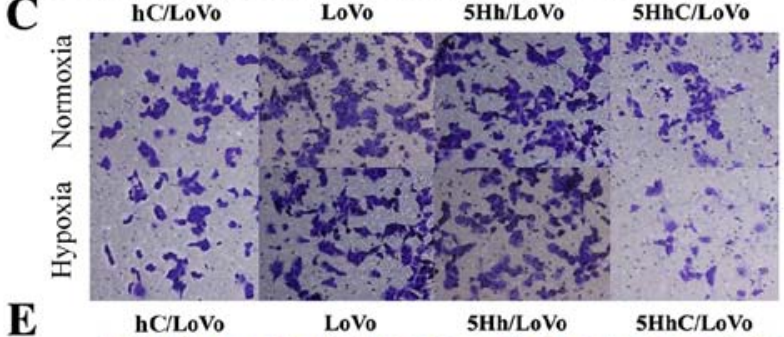

$\mathbf{E}$

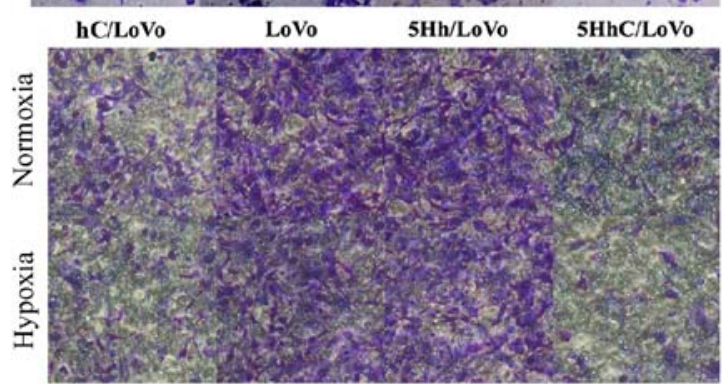

$\mathbf{B}$

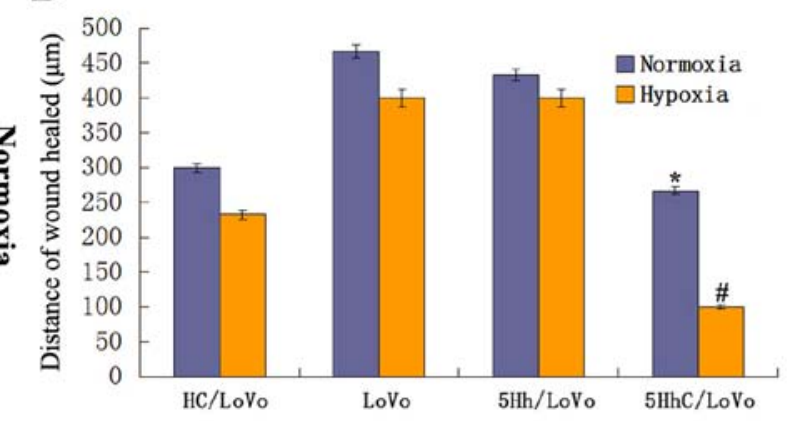

D

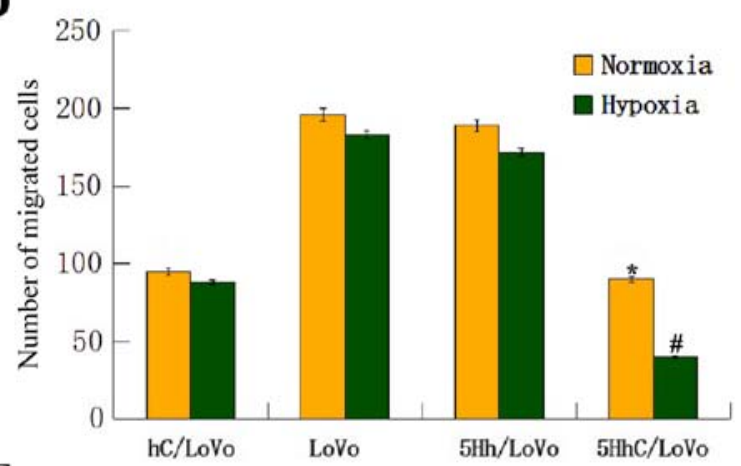

$\mathbf{F}$

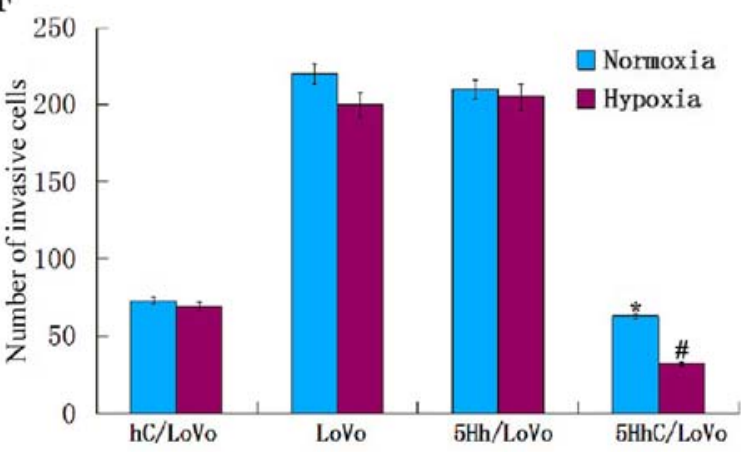

Figure 3. Migration and invasion of LoVo cells in all groups under normoxic and hypoxic conditions. (A and B) 5HhC/LoVo cells in the wound-healing assay migrated slower compared with control LoVo and $5 \mathrm{Hh} / \mathrm{LoVo}$ cells, especially under hypoxic condition. ( $\mathrm{P}<0.05$ compared to LoVo, $5 \mathrm{Hh} / \mathrm{LoVo}$ under normoxia; "P<0.05 compared to hc/LoVo, LoVo, 5Hh/LoVo under hypoxia). (C and D) 5HhC/LoVo cells displayed decreased migration ability compared with control LoVo and $5 \mathrm{Hh} / \mathrm{LoVo}$ cells, especially under hypoxic condition, ( ${ }^{*} \mathrm{P}<0.05$ compared to LoVo, $5 \mathrm{Hh} / \mathrm{LoVo}$ under normoxia; ${ }^{*} \mathrm{P}<0.05$ compared to hc/LoVo, LoVo, 5Hh/LoVo under hypoxia). (E and F) 5HhC/LoVo cells displayed decreased invasion ability compared with control LoVo and 5Hh/LoVo cells, especially under hypoxic conditions. ( ${ }^{*} \mathrm{P}<0.05$ compared to LoVo, $5 \mathrm{Hh} / \mathrm{LoVo}$ under normoxia; ${ }^{*} \mathrm{P}<0.05$ compared to he/LoVo, LoVo, $5 \mathrm{Hh} / \mathrm{LoV}$ o under hypoxia). The data shown are representative images of each group of cells from 3 separate experiments. The results are shown as means \pm SD.

Expression of CDX2 in LoVo cells inhibits cell proliferation and clonogenicity by restraining the G1 to $S$ transition. To investigate the effects of exogenous CDX2 expression in $5 \mathrm{HhC} /$ LoVo, we performed MTT and colony-formation assays using hC/LoVo, LoVo, 5Hh/LoVo, and 5HhC/LoVo cells under normoxic or hypoxic conditions. The MTT assay showed that $\mathrm{hC} / \mathrm{LoVo}$ and $5 \mathrm{HhC} / \mathrm{LoV}$ cells grew much slower than the control LoVo and $5 \mathrm{Hh} / \mathrm{LoV}$ cells under normoxic conditions (Fig. 2A). 5HhC/LoVo cells under hypoxic conditions showed the least growth among all cells (Fig. 2B), suggesting that CDX2 expression in $5 \mathrm{HhC} / \mathrm{LoVo}$ inhibited cell proliferation. As shown in Fig. 2C and D, exogenous CDX2 expression in 5HhC/LoVo also led to decreased colony numbers and colony size in the colony-formation assay, especially under hypoxic conditions. These observations indicated that the CDX2 expression reduced proliferation and clonogenic growth of LoVo cells in vitro.
Furthermore, the cell cycle analysis of the hC/LoVo and $5 \mathrm{HhC} / \mathrm{LoVo}$ cells showed a higher population of cells in the G0/G1 phases (63.59 and 64.82\%) compared to the control LoVo and 5Hh/LoVo cells (51.38 and 51.59\%) under normoxic conditions. The highest percentage of cells in the G0/G1 phases of $5 \mathrm{HhC} / \mathrm{LoVo}$ cells was observed under hypoxic conditions (Fig. 2E). These results suggest that CDX2 inhibits cell proliferation and tumorigenicity by preventing G1-to-S transition.

Exogenous CDX2 expression in LoVo cells promotes apoptosis. Annexin V-FITC/propidium iodide flow cytometry was used to assess the effect of CDX2 expression on apoptosis. In Fig. 2F, the fourth quadrant (Q4) represents early apoptotic cells and the second quadrant $(\mathrm{Q} 2)$ represents late apoptotic and necrotic cells. The results showed that $\mathrm{hC} / \mathrm{LoVo}$ and $5 \mathrm{HhC} / \mathrm{LoV}$ underwent increased apoptosis, compared with 
Table II. Percentages of cells in each phase of the cell cycle and apoptotic cells.

\begin{tabular}{llcccc}
\hline Group & Condition & G0/G1 & S & G2/M & Apoptosis \\
\hline hC/LoVo & Normoxia & $63.59 \pm 0.55$ & $26.01 \pm 2.21$ & $10.40 \pm 1.32$ & $9.03 \pm 1.93$ \\
& Hypoxia & $63.65 \pm 0.44$ & $21.94 \pm 2.04$ & $14.41 \pm 0.98$ & $9.25 \pm 1.69$ \\
LoVo & Normoxia & $51.38 \pm 0.70$ & $30.02 \pm 0.66$ & $18.60 \pm 1.13$ & $4.25 \pm 1.17$ \\
& Hypoxia & $51.44 \pm 0.56$ & $26.73 \pm 0.61$ & $21.83 \pm 1.25$ & $5.97 \pm 0.85$ \\
$5 \mathrm{Hh} /$ LoVo & Normoxia & $51.59 \pm 0.38$ & $36.19 \pm 1.12$ & $12.22 \pm 0.30$ & $4.92 \pm 0.92$ \\
& Hypoxia & $52.60 \pm 0.99$ & $32.04 \pm 1.23$ & $15.36 \pm 0.17$ & $5.65 \pm 0.99$ \\
$5 \mathrm{HhC} /$ LoVo & Normoxia & $64.82 \pm 2.22^{\mathrm{a}}$ & $24.88 \pm 1.98$ & $10.30 \pm 0.32$ & $12.58 \pm 2.38^{\mathrm{a}}$ \\
& Hypoxia & $71.38 \pm 3.02^{\mathrm{b}}$ & $20.62 \pm 1.59$ & $8.00 \pm 0.33$ & $21.2 \pm 2.26^{\mathrm{b}}$ \\
\hline
\end{tabular}

${ }^{\text {a }} \mathrm{P}<0.05$ compared to LoVo, 5Hh/LoVo under normoxia; ${ }^{\text {b}} \mathrm{P}<0.05$ compared to he/LoVo, LoVo, 5Hh/LoVo under hypoxia.

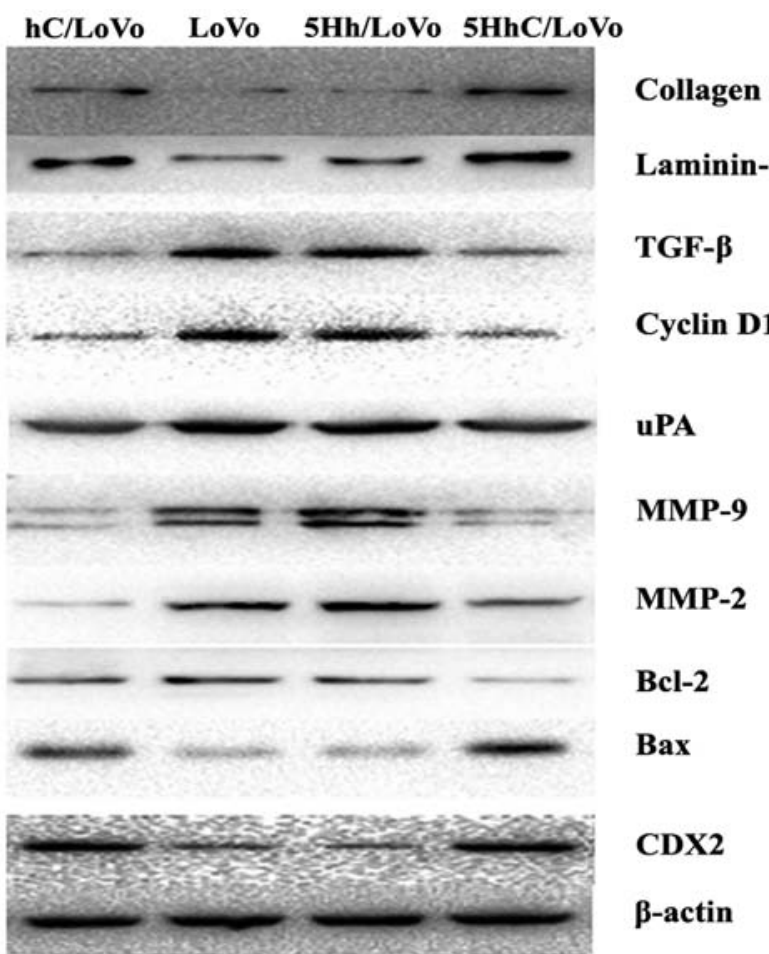

Figure 4. Expression of collagen IV, laminin-1, TGF- $\beta$, Cyclin D, uPA, MMP-2, MMP-9, bcl-2 and bax protein in hC/LoVo, LoVo, 5Hh/LoVo, $5 \mathrm{HhC} / \mathrm{LoV}$ o cells.

LoVo and 5Hh/LoVo cells, with the greatest effect observed under hypoxic conditions (Table II).

Effects of CDX2 overexpression in 5HhC/LoVo on cell invasion and migration potential. To investigate the effect of CDX2 overexpression in $5 \mathrm{HhC} / \mathrm{LoVo}$ on cell invasion and migration, wound-healing, and Transwell assays were performed in all groups of LoVo cell lines under normoxic or hypoxic conditions. The wound-healing assay clearly showed that $5 \mathrm{HhC} / \mathrm{LoV}$ o cells had reduced migration, especially under hypoxic conditions, since the remaining scratches in the wells containing CDX2-expressing cells were wider than in the controls (Fig. 3A and B). Furthermore, random microscopic fields of invading and migrating cells transfected with $\mathrm{hC}$, $5 \mathrm{Hh}, 5 \mathrm{HhC}$, or untreated LoVo cells under normoxic and hypoxic conditions are shown in Fig. 3C-F. The histogram shows that the number of invading or migrating cells transfected with $\mathrm{hC}$ and $5 \mathrm{HhC}$ was significantly lower than in cells transfected with $5 \mathrm{Hh}$ or untreated LoVo cells. The lowest number of invading or migrating cells was seen in $5 \mathrm{HhC} / \mathrm{LoV}$ o cells under hypoxic conditions. These results showed that overexpression of CDX2 substantially decreased migration and invasion of LoVo cells, especially under hypoxic conditions.

The effect of CDX2 on the expression of collagen $I V$, laminin-1, TGF- $\beta$, cyclin D1, uPA, MMP-2, MMP-9, bcl-2, and bax. We used western blotting to examine how CDX2 regulates the expression of proteins involved in proliferation, apoptosis, migration, and invasion under normoxic conditions. The western blot results showed that overexpression of CDX2 in $\mathrm{hC} / \mathrm{LoVo}$ and $5 \mathrm{HhC} / \mathrm{LoV}$ cells upregulated expression of collagen IV, laminin-1 and bax protein. In contrast, the expression of TGF- $\beta$, cyclinD, uPA, MMP-9, MMP-2, and BCL-2 protein was decreased by CDX2 (Figs. 4 and 5).

Overexpression of CDX2 in 5HhC/LoVo inhibited tumorigenicity in vivo. LoVo cells $\left(5 \times 10^{6}\right)$ were injected into athymic nude mice and monitored for 18 days. At the end of the study, the tumors were removed and dissociated, and both the volume and the weight of the tumors were determined (Fig. 6A). The volume of xenograft tumors in the hC/LoVo and $5 \mathrm{HhC} / \mathrm{LoV}$ groups revealed an obvious difference compared with the LoVo and 5Hh/LoVo groups (Fig. 6B), especially in the $5 \mathrm{HhC} / \mathrm{LoV}$ o group. Similarly, hC/LoVo and $5 \mathrm{HhC} / \mathrm{LoV}$ cells formed smaller subcutaneous tumors than did LoVo and 5Hh/LoVo cells (Fig. 6C). The mean tumor weights in mice of the hc, LoVo, $5 \mathrm{Hh} / \mathrm{LoVo}$, and $5 \mathrm{HhC}$ groups were $0.337 \pm 0.106 \mathrm{~g}, 0.609 \pm 0.302 \mathrm{~g}, 0.551 \pm 0.158 \mathrm{~g}$ and $0.201 \pm 0.112 \mathrm{~g}$, respectively. The tumors formed by $\mathrm{hC} / \mathrm{LoVo}$ and $5 \mathrm{HhC} / \mathrm{LoVo}$ cells showed less $\mathrm{Ki}-67$ expression than tumors formed by LoVo and $5 \mathrm{Hh} / \mathrm{LoVo}$ cells, with the lowest level of Ki-67 expression in the $5 \mathrm{HhC} /$ LoVo group (Fig. 7). These results confirmed that CDX2 inhibits proliferation of cancer cells in vivo. 


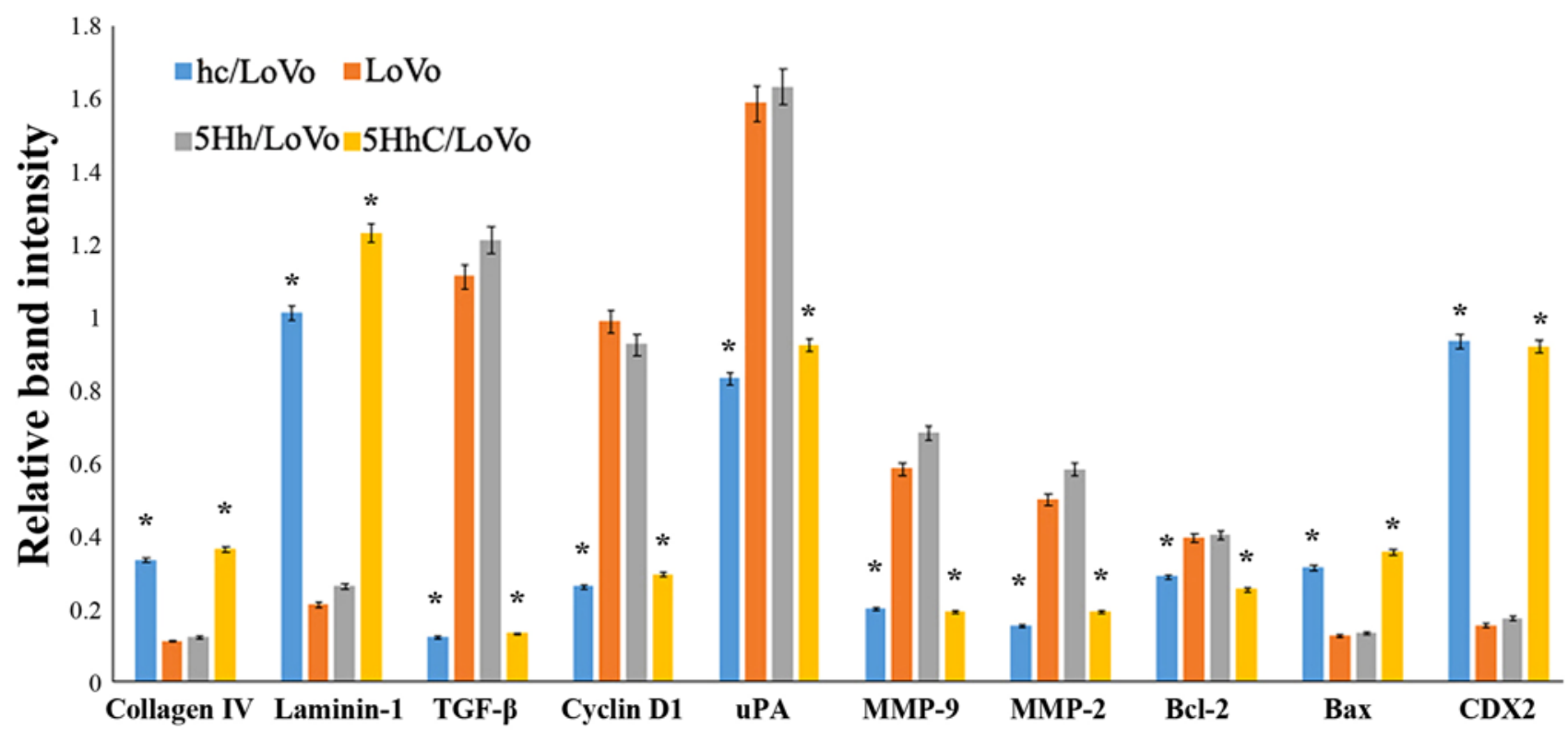

Figure 5. Relative expression of collagen IV, laminin-1, TGF- $\beta$, Cyclin D, uPA, MMP-2, MMP-9, bcl-2 and bax protein in hC/LoVo, LoVo, 5Hh/LoVo, 5HhC/LoVo cells. (" $\mathrm{P}<0.05$ compared to LoVo, 5Hh/LoVo under normoxia). Each experiment was performed in triplicate.

A

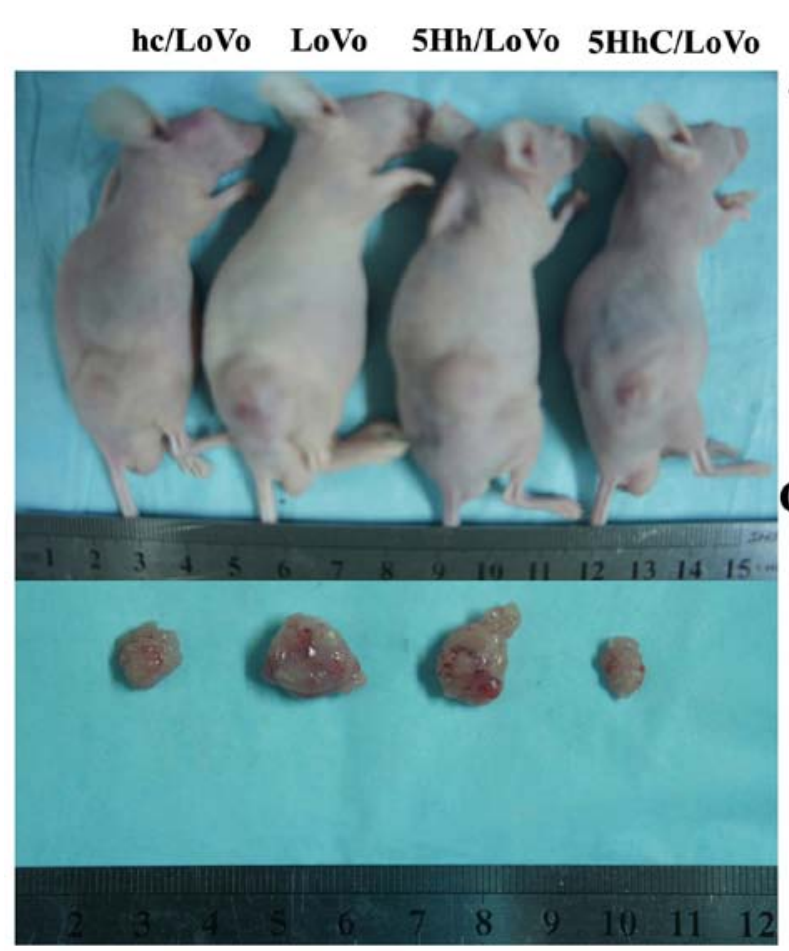

B

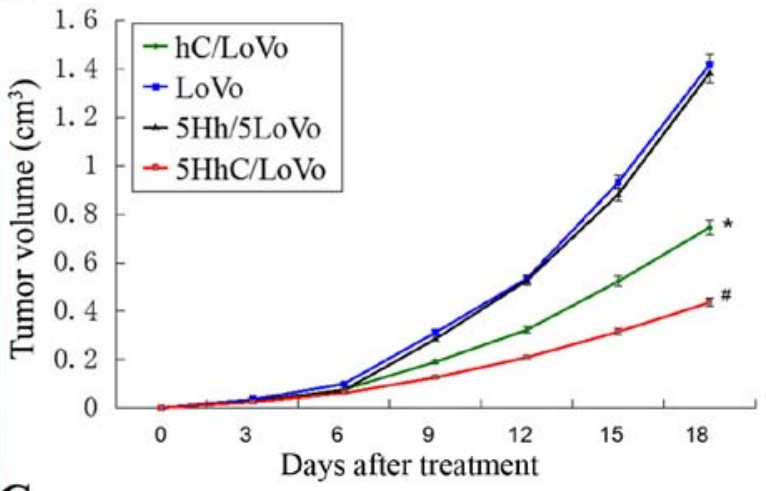

C

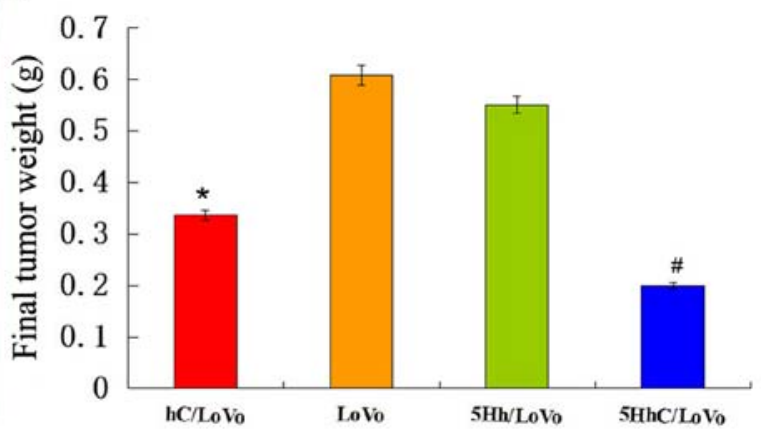

Figure 6. $5 \mathrm{HhC}$ suppresses the growth of subcutaneous tumors after injection of colon cancer cells invivo. (A) Representative tumor pictures are shown. (B) Tumor volume was recorded every 3 days. ( $\mathrm{P}<0.05$ compared to LoVo, $5 \mathrm{Hh} / \mathrm{LoVo}$; ${ }^{*} \mathrm{P}<0.01$ compared to LoVo, $5 \mathrm{Hh} / \mathrm{LoVo}$ ). (C) Tumor weight was determined on the eighteenth day. Data are presented as mean $\pm \mathrm{SD}$ of six mice in each group. ( ${ }^{*} \mathrm{P}<0.05$ compared to LoVo, $5 \mathrm{Hh} / \mathrm{LoVo}$; ${ }^{*} \mathrm{P}<0.01 \mathrm{compared}$ to LoVo, $5 \mathrm{Hh} / \mathrm{LoVo})$.

\section{Discussion}

Gene therapy is a promising option for the treatment of human cancers. However, two keys to success, the persistent expression of anticancer gene products, and a tumor-selective delivery system, remain elusive. CDX2 expression in adults is restricted to intestinal epithelial cells, where it maintains differentiated phenotype of mature enterocytes by regulating expression of intestine-specific genes, including lactase, sucrase-isomaltase, LI-cadherin, and guanylyl cyclase C (GCC) (29). In addition, CDX2 also functions as a tumor suppressor gene in the adult colon. Clinically and 
A
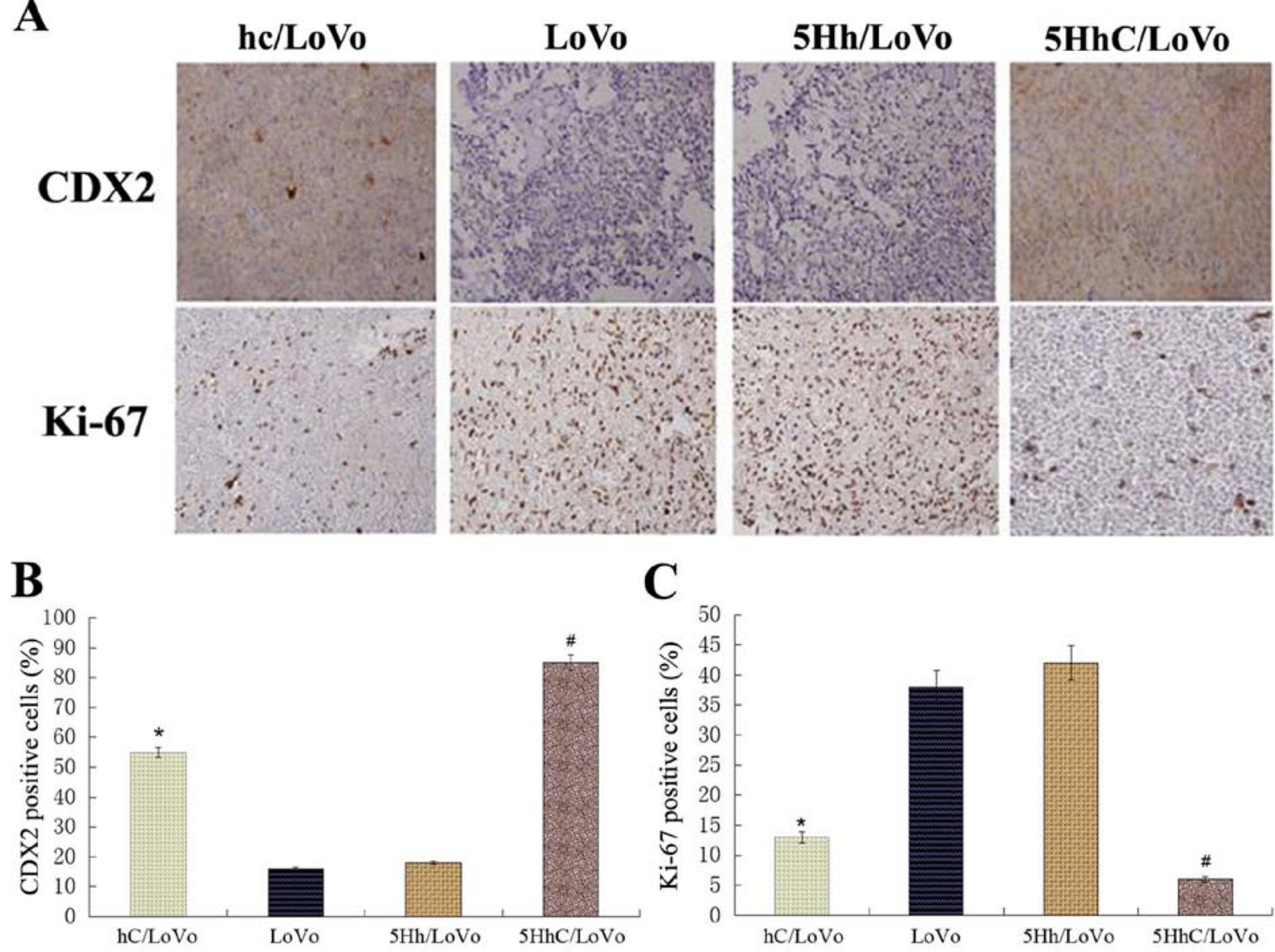

Figure 7. Immunohistochemical staining of tumor specimens for CDX2 and Ki-67. Data are presented as mean \pm SD of six mice in each group. ("P $<0.05$ compared to LoVo, $5 \mathrm{Hh} / \mathrm{LoVo}$; ${ }^{\#} \mathrm{P}<0.01$ compared to LoVo, $5 \mathrm{Hh} / \mathrm{LoV}$. Each experiment was performed in triplicate.

pathologically, CDX2 expression is decreased in human colorectal cancer, and reduced expression of CDX2 is associated with poor overall survival rates in colorectal cancer patients $(12,30,31)$. Histopathological studies have further established that CDX2 expression is reduced in invasive colorectal cancer cells, but is restored in metastases $(32,33)$. Our previous study confirmed that upregulation of CDX2 expression in human colon cancer cells inhibits invasion and migration in vitro and tumorigenicity in vivo $(13,34)$. Therefore, we chose to investigate further CDX2 as a potential agent for anticancer gene therapy.

A tumor-selective delivery system is the key to successful tumor gene therapy. The hTERT promoter, active in most cancer cells, but not in normal tissues, is used as a strategy for tumor-selective delivery (16,35-37). Hypoxia plays an important role in tumor development and tumor progression (38). Herein, we used 5 copies of the hypoxia responsive element (HRE) as an hTERT promoter enhancer (5HRE). The 5HRE element has previously been used as an enhancer to utilize the hypoxic microenvironment (39). Harvey et al (40) developed a hypoxia-targeted gene therapy strategy using the herpes simplex virus thymidine kinase and bacterial nitroreductase pro-drug-activating genes and showed that 5HRE linked to the CMV minimal promoter could induce optimum luciferase reporter gene expression. In our previous study, gene therapy vectors under the control of 5HRE and a minimal tumor specific promoter also displayed optimal activation at a low oxygen tension in hepatoma and gastric cancer cells $(25,41)$.

For gene therapy in colon cancer, we previously generated a recombinant lentivirus vector for hypoxia-inducible, hTERT promoter-driven, and tissue-specific expression of CDX2: pLVX-5HRE-hTERTp-CDX2-3FLAG (5HhC) (26). To verify the specificity and the activity of pLVX-5HREhTERTp-CDX2-3FLAG, the recombinant lentiviral vector was transfected into hTERT ${ }^{+}$cells (LoVo) and hTERT cells (HK-2). We confirmed by immunohistochemistry that the hTERT $^{+}$LoVo cells were infected with the recombinant lentiviral vector $5 \mathrm{HhC}$, while the hTERT HK-2 cells were not. The expression of CDX2 protein and mRNA was further increased by hypoxia in $5 \mathrm{HhC} / \mathrm{LoVo}$ cells, which was confirmed by western blotting and RT-PCR. Thus, we concluded that hypoxic microenvironment can increase the expression of CDX2 using gene therapy vector $5 \mathrm{HhC}$ which is regulated by the hypoxiainduced enhancer (HRE) and the hTERT promoter in hTERT ${ }^{+}$ LoVo cells (26). In the current study LoVo cells infected with pLVX-5HRE-hTERTp-CDX2-3FLAG lentivirus showed reduced cell viability, lower colony formation and invasive ability, but displayed increased apoptosis and cell cycle arrest under hypoxic conditions. Most significantly, pLVX-5HREhTERTp-CDX2-3FLAG suppressed colon cancer xenograft tumor formation and growth in nude mice. Although hypoxia 
causes downregulation of CDX2 expression in vivo and promotes progression of colorectal cancer (23), our current data indicate that pLVX-5HRE-hTERTp-CDX2-3FLAG can effectively utilize hypoxia to drive the antitumor activity of CDX2. Our current data strongly support the potential usefulness of pLVX-5HRE-hTERTp-CDX2-3FLAG as an effective antitumor treatment option for colorectal cancer.

However, the mechanism whereby CDX2 exerts antitumor properties and the downstream signaling pathways in colorectal cancer have not been elucidated. Some studies reported that CDX2 expression depends on the microenvironment and is regulated by laminin- 1 and collagen-1 $(42,43)$. In this study we demonstrated that CDX2 regulates the expression of collagen IV, laminin- 1 , TGF- $\beta$, cyclin D1, uPA, MMP-2, MMP-9, bcl-2 and bax protein in vitro, and of Ki-67 in vivo. The changes in the expression of these proteins may mediate the tumor suppressor role of CDX2. Our previous study established that exogenous expression of CDX2 in LoVo cells results in a significant decrease in MMP-2 secretion, which, subsequently, restrains cell invasion and migration in vitro (13). Supporting this result, Gross et al (8) showed increased expression of MMP-2 mRNA in SW480 cells upon siRNA-mediated inhibition of CDX2 and found that CDX2 expression is regulated by epithelial-mesenchymal transition (EMT)-inducing transcription factors such as Snail and Slug. Yusra et al (44) demonstrated that transduction of CDX2-expression vector into CD133+ SW480 cells effectively suppressed TGFBR1 and TGFBR3 expression but treatment with TGF- $\beta$ restored CD133 ${ }^{+}$SW480 cells and induced EMT. Wei et al (45) indicated that CDX2 promoted apoptosis in the MGC-803 human gastric cancer cell line in vitro and in vivo. Overexpression of CDX2 upregulated expression of Bax and downregulated levels of survivin, Bcl-2, cyclin D1, Skp2, and c-Myc in tumor tissues. Seno et al (46) showed that CDX2-positive gastric cancer tissue samples showed a significantly lower index for Ki-67 immunostaining. Even among intestinal-type gastric cancer cases, the CDX2-positive group showed a lower Ki-67 index and longer postoperative survival than did the CDX2-negative group. All of the above studies are in agreement with our current results, which confirmed that CDX2 acts as a tumor suppressor in colon cancer.

Much more work needs to be done to confirm the safety and efficiency of the pLVX-5HRE-hTERTp-CDX2-3FLAG lentivirus vector before our results can be translated into clinical trials. Our system may help to solve two key problems in gene therapy, that is, specificity and efficiency. We showed that by using this vector we can regulate gene expression in hTERT-positive colon cancer cells under hypoxic conditions, further ensuring the cancer cell-specific expression of therapeutic genes. In addition, this study confirms that the expression of CDX2 effectively inhibits the growth of colon cancer cells in vitro and in vivo. The system described in this study may provide a potential tool for treatment and gene therapy of colon cancer.

\section{Acknowledgements}

This work was supported by a grant from the National Natural Science Foundation of China (grant serial nos.: 81101874, 81172362), the Science and Technology Project of Shaanxi
Province (grant serial no.: 2016SF-015), the Coordinative and Innovative Plan Projects of the Science and Technology Program in Shaanxi Province (grant serial no.: 2013KTCQ03-08), and a Clinical Innovation Fund of First Affiliated Hospital of XJTU (grant serial nos.: 12ZD12, 12ZD21).

\section{References}

1. Siegel RL, Miller KD and Jemal A: Cancer statistics, 2016. CA Cancer J Clin 66: 7-30, 2016.

2. Shayakhmetov DM, Di Paolo NC and Mossman KL: Recognition of virus infection and innate host responses to viral gene therapy vectors. Mol Ther 18: 1422-1429, 2010.

3. Chen EQ, Song XQ, Wang YL, Zhou TY, Bai L, Liu L, Liu C, Cheng $\mathrm{X}$ and Tang H: Construction of a highly-active, liverspecific transcriptional regulatory element through combination of the albumin promoter and $\alpha$-fetoprotein enhancer. Plasmid 65: 125-131, 2011.

4. Dong K, Wang R, Wang X, Lin F, Shen JJ, Gao P and Zhang HZ: Tumor-specific RNAi targeting eIF4E suppresses tumor growth, induces apoptosis and enhances cisplatin cytotoxicity in human breast carcinoma cells. Breast Cancer Res Treat 113: 443-456, 2009.

5. Akhavan-Niaki $\mathrm{H}$ and Samadani AA: Molecular insight in gastric cancer induction: An overview of cancer stemness genes. Cell Biochem Biophys 68: 463-473, 2014.

6. Natoli M, Christensen J, El-Gebali S, Felsani A and Anderle P: The role of CDX2 in Caco-2 cell differentiation. Eur J Pharm Biopharm 85: 20-25, 2013.

7. Lin ME, Huang D, Deng BH, Lv YS, Rong L and Yao YS: Expression and functional role of $\mathrm{Cdx} 2$ in intestinal metaplasia of cystitis glandularis. J Urol 190: 1083-1089, 2013.

8. Gross I, Duluc I, Benameur T, Calon A, Martin E, Brabletz T, Kedinger M,Domon-Dell C and Freund JN: The intestine-specific homeobox gene $\mathrm{Cdx} 2$ decreases mobility and antagonizes dissemination of colon cancer cells. Oncogene 27: 107-115, 2008.

9. Aoki K, Tamai Y, Horiike S, Oshima M and Taketo MM: Colonic polyposis caused by mTOR-mediated chromosomal instability in $\mathrm{Apc}^{+} /$Delta716 Cdx2 $2^{+/}$compound mutant mice. Nat Genet 35: 323-330, 2003

10. Chawengsaksophak K, James R, Hammond VE, Köntgen F and Beck F: Homeosis and intestinal tumours in $\mathrm{Cdx} 2$ mutant mice. Nature 386: 84-87, 1997.

11. Olsen AK, Coskun M, Bzorek M, Kristensen MH, Danielsen ET, Jørgensen S, Olsen J, Engel U, Holck S and Troelsen JT: Regulation of APC and AXIN2 expression by intestinal tumor suppressor CDX2 in colon cancer cells. Carcinogenesis 34: 1361-1369, 2013.

12. Hong KD, Lee D, Lee Y, Lee SI and Moon HY: Reduced CDX2 expression predicts poor overall survival in patients with colorectal cancer. Am Surg 79: 353-360, 2013.

13. Zheng JB, Sun XJ, Qi J, Li SS, Wang W, Ren HL, Tian Y, Lu SY and Du JK: Effects of homeodomain protein CDX2 expression on the proliferation and migration of lovo colon cancer cells. Pathol Oncol Res 17: 743-751, 2011.

14. Wang W, Jin B, Li W, Xu CX, Cui FA, Liu B, Yan YF, Liu XX and Wang XL: Targeted antitumor effect induced by hTERT promoter mediated ODC antisense adenovirus. Mol Biol Rep 37: 3239-3247, 2010.

15. Bougel S, Renaud S, Braunschweig R, Loukinov D, Morse HC III, Bosman FT, Lobanenkov V and Benhattar J: PAX5 activates the transcription of the human telomerase reverse transcriptase gene in B cells. J Pathol 220: 87-96, 2010.

16. Zhang P, Tan J, Yang DB, Luo ZC, Luo S, Chen P, Sun P, Zhou Y, Chen XC, Wei YQ, et al: Gene therapy using the human telomerase catalytic subunit gene promoter enables targeting of the therapeutic effects of vesicular stomatitis virus matrix protein against human lung adenocarcinoma. Exp Ther Med 4: 859-864, 2012.

17. Hioki M, Kagawa S, Fujiwara T, Sakai R, Kojima T, Watanabe Y, Hashimoto Y, Uno F, Tanaka N and Fujiwara T: Combination of oncolytic adenovirotherapy and Bax gene therapy in human cancer xenografted models. Potential merits and hurdles for combination therapy. Int J Cancer 122: 2628-2633, 2008.

18. Gout S and Huot J: Role of cancer microenvironment in metastasis: Focus on colon cancer. Cancer Microenviron 1: 69-83, 2008. 
19. Jubb AM, Buffa FM and Harris AL: Assessment of tumour hypoxia for prediction of response to therapy and cancer prognosis. J Cell Mol Med 14: 18-29, 2010.

20. Law AY, Ching LY, Lai KP and Wong CK: Identification and characterization of the hypoxia-responsive element in human stanniocalcin-1 gene. Mol Cell Endocrinol 314: 118-127, 2010

21. Zhang J, Shi Q, Chen X, Yang P, Qi C, Zhang J, Lu H, Liu J, Jiao Q, Zhao L, et al: Hypoxia-regulated neurotrophin-3 expression by multicopy hypoxia response elements reduces apoptosis in PC12 cells. Int J Mol Med 30: 1173-1179, 2012.

22. Hu J, Stiehl DP, Setzer C, Wichmann D, Shinde DA, Rehrauer H Hradecky P, Gassmann M and Gorr TA: Interaction of HIF and USF signaling pathways in human genes flanked by hypoxiaresponse elements and E-box palindromes. Mol Cancer Res 9: 1520-1536, 2011.

23. Zheng J, Sun X, Wang W and Lu S: Hypoxia-inducible factor-1a modulates the down-regulation of the homeodomain protein CDX2 in colorectal cancer. Oncol Rep 24: 97-104, 2010.

24. Shibata T, Giaccia AJ and Brown JM: Development of a hypoxiaresponsive vector for tumor-specific gene therapy. Gene Ther 7 : 493-498, 2000

25. Zhou PH, Zheng JB, Wei GB, Wang XL, Wang W, Chen NZ, Yu JH, Yao JF, Wang H, Lu SY, et al: Lentivirus-mediated RASSF1A expression suppresses aggressive phenotypes of gastric cancer cells in vitro and in vivo. Gene Ther 22: 793-801, 2015.

26. He S, Sun XJ, Zheng JB, Qi J, Chen NZ, Wang W, Wei GB, Liu D, $\mathrm{Yu} \mathrm{JH}, \mathrm{Lu} \mathrm{SY}$, et al: Recombinant lentivirus with enhanced expression of caudal-related homeobox protein 2 inhibits human colorectal cancer cell proliferation in vitro. Mol Med Rep 12 . 1838-1844, 2015.

27. Ji J and Zheng PS: Expression of Sox 2 in human cervical carcinogenesis. Hum Pathol 41: 1438-1447, 2010.

28. Li X, Wang K, Ren Y, Zhang L, Tang XJ, Zhang HM, Zhao CQ, Liu PJ, Zhang JM and He JJ: MAPK signaling mediates sinomenine hydrochloride-induced human breast cancer cell death via both reactive oxygen species-dependent and -independent pathways: An in vitro and in vivo study. Cell Death Dis 5: e1356, 2014.

29. Witek ME, Snook AE, Lin JE, Blomain ES, Xiang B, Magee MS and Waldman SA: A novel CDX2 isoform regulates alternative splicing. PLoS One 9: e104293, 2014.

30. Bae JM, Lee TH, Cho NY, Kim TY and Kang GH: Loss of CDX2 expression is associated with poor prognosis in colorectal cancer patients. World J Gastroenterol 21: 1457-1467, 2015

31. Olsen J, Eiholm S, Kirkeby LT, Espersen ML, Jess P, Gögenür I, Olsen J and Troelsen JT: CDX2 downregulation is associated with poor differentiation and MMR deficiency in colon cancer. Exp Mol Pathol 100: 59-66, 2016.

32. Dawson H, Koelzer VH, Lukesch AC, Mallaev M, Inderbitzin D, Lugli A and Zlobec I: Loss of Cdx2 expression in primary tumors and lymph node metastases is specific for mismatch repair-deficiency in colorectal cancer. Front Oncol 3: 265, 2013.

33. Olsen J, Espersen ML, Jess P, Kirkeby LT and Troelsen JT: The clinical perspectives of CDX2 expression in colorectal cancer: A qualitative systematic review. Surg Oncol 23: 167-176, 2014.
34. Zheng JB, Qiao LN, Sun XJ, Qi J, Ren HL, Wei GB, Zhou PH, Yao JF, Zhang L and Jia PB: Overexpression of caudal-related homeobox transcription factor 2 inhibits the growth of transplanted colorectal tumors in nude mice. Mol Med Rep 12: 3409-3415, 2015.

35. Xu Y, Hou J, Liu Z, Yu H, Sun W, Xiong J, Liao Z, Zhou F, Xie $C$ and Zhou Y: Gene therapy with tumor-specific promoter mediated suicide gene plus IL-12 gene enhanced tumor inhibition and prolonged host survival in a murine model of Lewis lung carcinoma. J Transl Med 9: 39, 2011

36. Zhang Y, Toh L, Lau P and Wang X: Human telomerase reverse transcriptase (hTERT) is a novel target of the Wnt/ $\beta$-catenin pathway in human cancer. J Biol Chem 287: 32494-32511, 2012.

37. Shepelev MV, Kopantzev EP, Vinogradova TV, Sverdlov ED and Korobko IV: hTERT and BIRC5 gene promoters for cancer gene therapy: A comparative study. Oncol Lett 12: 1204-1210, 2016.

38. Paolicchi E, Gemignani F, Krstic-Demonacos M, Dedhar S, Mutti L and Landi S: Targeting hypoxic response for cancer therapy. Oncotarget 7: 13464-13478, 2016.

39. Zhang H, Liang C, Hou X, Wang L and Zhang D: Study of the combined treatment of lung cancer using gene-loaded immunomagnetic albumin nanospheres in vitro and in vivo. Int $\mathrm{J}$ Nanomed 11: 1039-1050, 2016.

40. Harvey TJ, Hennig IM, Shnyder SD, Cooper PA, Ingram N, Hall GD, Selby PJ and Chester JD: Adenovirus-mediated hypoxia-targeted gene therapy using HSV thymidine kinase and bacterial nitroreductase prodrug-activating genes in vitro and in vivo. Cancer Gene Ther 18: 773-784, 2011.

41. Wang W, Sun X, Lu L, Zheng JB, Tian Y and Wang W: Cytotoxicity of lymphocytes activated by superantigen toxicshock-syndrome toxin-1 against colorectal cancer LoVo cells. Mol Cell Biochem 376: 1-9, 2013.

42. Brabletz T, Spaderna S, Kolb J, Hlubek F, Faller G, Bruns CJ, Jung A, Nentwich J, Duluc I, Domon-Dell C, et al: Downregulation of the homeodomain factor $\mathrm{Cdx} 2$ in colorectal cancer by collagen type I: An active role for the tumor environment in malignant tumor progression. Cancer Res 64: 6973-6977, 2004.

43. Turck N, Gross I, Gendry P, Stutzmann J, Freund JN, Kedinger M, Simon-Assmann P and Launay JF: Laminin isoforms: Biological roles and effects on the intracellular distribution of nuclear proteins in intestinal epithelial cells. Exp Cell Res 303: 494-503, 2005.

44. Yusra, Semba S and Yokozaki H: Biological significance of tumor budding at the invasive front of human colorectal carcinoma cells. Int J Oncol 41: 201-210, 2012.

45. Wei W, Li L, Wang X, Yan L, Cao W, Zhan Z, Zhang X, Yu H, Xie Y and Xiao Q: Overexpression of caudal type homeobox transcription factor 2 inhibits the growth of the MGC-803 human gastric cancer cell line in vivo. Mol Med Rep 12: 905-912, 2015.

46. Seno H, Oshima M, Taniguchi MA, Usami K, Ishikawa TO Chiba T and Taketo MM: CDX2 expression in the stomach with intestinal metaplasia and intestinal-type cancer: Prognostic implications. Int J Oncol 21: 769-774, 2002. 